\title{
Moral Competence and Aggression Prevention. Updating MCT Pilot Studies Inspired by Georg Lind's Book How to Teach Morality. Promoting Deliberation and Discussion, Reducing Violence and Deceit (2016)
}

\author{
Ewa Nowak \& Adrianna Urbańska \\ (Adam Mickiewicz University of Poznań, ewanowak@bluewin.ch, urbanska@gmail.com)
}

\section{Aggression Today}

We have updated our study for the following reason: to show that promoting moral and discourse competence in juveniles can protect the entire society against the increase of aggressive behavior. We do not refer here to the therapeutic treatment of aggression, but only to the educational, specifically based on the Konstanz Method of Dilemma Discussion (Lind 2016, 1997). Educational prevention of aggression is viewed here as a remedy against social helplessness in the face of interpersonal conflicts and as a reasonable alternative to institutional sanctions and political oppression (Freire 2000, Lind \& Nowak 2009). Social helplessness can be observed when dealing with interpersonal conflicts when reason, speech, dialogue and other democratic means stop working. That might constitute a breaking point which moves even democratic peoples to introduce sanctions and oppressive institutions, and to elect authoritarian leadership, because these peoples face both aggression around them and the helplessness in themselves. Democratic peoples are even showing a readiness to abandon "a piece of autonomy" to their strong leaders (Lind 2016, 45) to increase their safety. Such dialectics of low moral competence in citizens and a high concentration of power in authoritarian leaders is becoming popular in "countries with low levels of education" (Lind 2016 , 48). Historical experience teaches that democracy can quickly transition to dictatorship by means of peoples' legitimization. Such developments may even lead to the termination of supranational conventions on preventing and combating violence. To avoid such an acceleration of the "spiral of violence" and the "circle of hostile attributions" (Lind 1993, 13) in social relations of all kinds, societies need efficient education programs, at least for juveniles.

In Poland we observe protests which are democratic as long as the protesters are competent enough to respect everyone's human dignity and personal inviolability. Those protesters may be moved by civil disobedience, and by understood and appropriately chanelled thumos (Sloterdijk 2011), but they should avoid violence, the destruction of property, and related means which would lead them to harm, persecute and oppress others. A large number of engaged protesters is to be expected in all political regimes which 
presuppose the inclusion of citizens as agents enabled to act constructively, e.g., not passive spectators or just passionate actors (Koyama 2012).

To round off this psycho-political introduction, we would like to draw attention to the Polish educational and socializational context. The Polish education system performs well in PISA rankings and is due to start new reforms in 2017, but it is impoverished when it comes to the training of sociomoral competences and violence-free conflict resolution. Schools and teachers are unable to empower and re-empower pupils against the development of aggressive behavior, xenophobia, discrimination, "destructive fanaticism" (Freire 2005, 35) and other dangerous phenomena. Research studies like ours call for the promotion of professional training and teaching methods oriented towards the prevention of aggression prevention through the strengthening of moral cognition and moral competence in students1. Such methods seem to be the most efficient and promising tool for bringing about a nonviolent society. Citizens with strong moral competence are able to say "Leaders... the People are speaking! We are united. We are our own voice," "Stay united and peaceful! Be heard!" (New Yorker protesters at JFK Terminal on 29 January, 2017, FB). Lind's research findings confirm Freire's assertion (2000) that: "strong individuals do not use violence"; and Lind adds, "and where force is necessary they keep it within the limits of democratic laws (...) Finally, it seems that with the help of the concept of moral competence, we can also overcome the limitations of non-cognitive theories of moral development and education" (Lind 2016, 48), i.e., theories of indoctrination, imparting values, mimetic socialization, and physical violence, which were tools employed when raising children in archaic systems, and are still popular in authoritarian political systems.

\section{The Emotional Approach To Morality And Its Limitations}

Celebrating emotions as the omnipotent premises of moral conduct reached its apotheosis with Jonathan Haidt (2001), Frans de Waal (2016) and many others. The career of the theory of emotional intelligence (Cavelzani \& Esposito 2010) is impressive too.

However, raw, uncultivated and strong emotions are too labile and ungovernable to provide moral conduct with reliable and justifiable motives. Thus, moral cognition remains a necessary aspect of moral judgments and decisions in complex, interpersonal and interactive contexts that are social and institutional. In those contexts, moral cognition manifests itself in violence-free

\footnotetext{
1 The authors would like to thank Dr. Marta Mazurek (from the Municipal Office Against Discrimination of City Hall in Poznań, Poland) for her engagement in violencefree local community and the execution of the Council of Europe Convention on preventing and combating domestic violence.
} 
discourse acts, in which reason experiences itself as human "thinking codified in language" (Habermas 1986, 286), including illocutionary and perlocutionary forces replacing physical interplay such as violence, pressure, and manipulation. But discourse is not everything: it can also be laden with aggression, oppression and hate speech (Freire 2005). Unfortunately, only a few experts are familiar with the complex principle of discourse ethics established by Jürgen Habermas and Karl-Otto Apel (2017). The link between cognition, principled judgment, the self-control of aggression and violence-free social practice needs to be explored in order to uncover how we can protect our societies against the escalation of uncontrolled aggression and violence. Empowering sensitivity and empathy to more efficiently combat violence is not enough, either. It might even be counter-productive ${ }^{2}$, as we show in the next section. The issue of disconnecting moral cognition from strong emotions, including excessive empathy (Bloom 2016) and hostility, as well as anger and rage, has animated most recent discussions on how human beings make adequate decisions (Bloom 2016) in demanding social contexts. According to Greene, "deontological judgments are associated with increasing activity in the dorsolateral prefrontal cortex, a brain region associated with cognitive control" (Greene 2009, 583; see also Miller \& Cohen 2001). This is the case particularly when a person is confronted with socio-moral conflicts, or dilemmas. Making moral judgment should engage cognitive reflection and be accompanied by an emotional response (Greene et al. 2001, 2009; Bartels 2008) instead of being reduced to a purely emotional response. The "respective role" of emotion and cognition in human judgment in the face of "high conflict personal dilemmas" (Greene 2009, 582) and interpersonal conflicts, in particular when the other party uses violent means, remains underexamined. What is already known is that emotional conflicts and high affect overwhelm a person's cognitive skills and evoke "negative emotional response conflicts" (Greene 2009, 582). Persons' decisions and behaviors are difficult for them to navigate themselves, as they are diminished in cognitive processing, reflective and principled judgment making, and meta-reflection. For these reasons, the authors (Lind

2 According to P. Bloom, an excessive empathy and sensitiveness weaken moral subjects and may lead to generous but unjust decisions. Freire explains that weakness in terms of his theory of liberation: "only power that springs from the weakness of the oppressed will be sufficiently strong to free both [the oppressed and the oppressor]. Any attempt to 'soften' the power of the oppressor in deference to the weakness of the oppressed almost always manifests itself in the form of false generosity; indeed, the attempt never goes beyond this. In order to have the continued opportunity to express their 'generosity,' the oppressors must perpetuate injustice as well. An unjust social order is the permanent fount of this "generosity," which is nourished by death, despair, and poverty" (Freire 2005, 45). With power which can protect a person against false generosity, injustice and violent behavior we mean strong moral cognition and interhuman discourse. Cognition and discourse are too fundamental for civil disobedience and legitimate anger (see Rawls 1999, Thoreau 1849, Pearson 2001). 
2016, Bloom 2016, Greene 2009) advocate the primacy of moral cognition instead of that of moral affect (Piaget 1981). For Lind, cognition and emotion "are much more closely connected than we think" (Lind 2016, 29). For Bloom (2016) they should be disconnected when people aspire to make adequate, right and just moral judgments. Fortunately, "although they are innate, our feelings change and develop as a result of our experiences. That is, we ourselves can use our judgment and reason to influence them purposefully through training" (Lind 2016, p. 29). Linking the recent cognitive turn, social context-related empathy, and the self-control of aggression together, Martha Nussbaum points out that "children who develop a capacity for sympathy or compassion-often through empathetic perspectival experience-understand what their aggression has done to another separate person" (Nussbaum 2010, 37). In sum, "empathy is not morality" (cf., 37). Practical decisions, which move persons to action, require more than (even the best and high) affective excitement. They require a trained moral and discourse competence (Lind 2016, 29-36). Unfortunately, "'natural' opportunities for moral learning are out of reach for children" (Lind 2016, 31) even in democratic societies. They must be created by professionals in classrooms. A basic moral competence cannot be defined in terms of evolutionary biology and the physiology of the brain. It is "the ability to solve problems and conflicts on the basis of universal moral principles through thinking and discussion, instead of using violence, deceit, and force. Based on this definition ..." (Lind 2016, 45) we cannot expect advanced ethical and meta-ethical operations such as the justification of social conventions and lawgiving. Lind's definition stresses the ability to apply already proved and approved internal principles that people actually respect when making moral decisions. Of course, some people examine principles and their justifications too, but the majority of non-experts have no chance of reaching such advances in their cognitive development, for many systemic and personal reasons. Moral competence offers just a rational, discursive and efficient alternative against both violence and helplessness when a decision maker is challenged by a socio-moral conflict. Consequently,

Based on this definition, we assume that the greater the problem, the better this ability must be developed. If the problems grow over our heads because social change is great, but our educational institutions (parents, schools, and universities) have not given sufficient opportunity for the development of moral competence, then we fall back on lower forms of conflict resolution such as violence, fraud, and force. If that also does not help, then we call for a strong power that solves our problems and conflicts for us which amounts to the abolition of democratic coexistence in favor of dictatorship (Lind 2016, 45) ${ }^{3}$.

\footnotetext{
3 Strengthened moral competence complements value education often celebrated as a
} panacea for conflicts, hostility, violence etc. However, values in plenty and diversity as 


\section{The Strength of Humans is Moral Competence, Aggression Is Their Weakness}

The growth of moral competence has a distinct impact on increasing the selfcontrol of aggressive behavior and violence (Lind 2010, 2016). According to Lind $(1977,1)$, violent behavior correlates with the lowest level of moral competence. Lind disagrees with the statement that aggression is a lasting stigmatic and devilish attitude in the personality, or that "good people" suddenly "turn evil" and become "perpetrators of violence" (Zimbardo 2007, xi). It is cognition that protects people from employing violence; and it is cognition that allows them to deal with conflicts and problems in a rational and peaceful way. It is "cognitive processes that decide about how long, how explosive, how strong or how weak the aggressive reaction will be performed" (Lind 1993, 15). A positive correlation between high moral competence and the rejection of violence was found by Peisert, Bargel, Lind et al. (FORM project, $\mathrm{N}=2000$ ). Whereas the "deficient competence of solving problems" ("mangelnde Problemlösefähigkeit") was identified as a contributor to violent behaviors (Lind 1993/2010, 4).

There is no place for aggression in human life and society because humans have no natural predators. However, according to modern anthropologists - especially Herder and Gehlen - the human condition is imperfect, "vulnerable," "frail and weak" (Mängelwesen) (Herder 2016, 97; Gehlen 1981). Instinctive aggression empowers non-human living beings against their natural enemies, but in case of humans, instinctive aggression implies a weakness of the human as a social and cultural being as well. As it leads to violence and conflict between kinsman, aggression is destructive for humanity, humanness and human development. Yet the unique strength of humans is embodied in their cognition, awareness, language and thinking, and in their use of dialogue as the best protection against violence, as the foundation of peace, and as the most favorable opportunity for human growth. These protections are not really natural; they are only nurtured by some biological resources shared with other animals. In their essence, their are artificial and cultural. They may easily regress and disappear when humans are uncultivated, mal-educated (Lind 1985), or oppressed (Lind \& Nowak 2009). The anthropological approach we briefly recalled here shows aggression to be a biological relic in humankind. Humanity must deal with it in a way that is probably impossible for non-human animals.

known today can neither be melted together nor offer one 'regulatory' system for all. Rather, it is a legal regulatory system's role to protect an equal free room for individuals to follow their values, as Gustav Radbruch (2003) puts it. Moral competence enables individuals to manage that free room autonomously, with respect for others. 
Still, such classic theories only provide a general approach to human aggression. Neither the social sciences nor evolutionary biology and psychology have managed to elaborate a comprehensive explanation of aggression for special cases and new social opportunities (for example, feeling endangered by terror attacks or sharing a parent cultural habitat with radically other cultures). Conflict psychology and conflict neuroscience also show that situations involving conflict between human beings are perceived and interpreted as "dangerous" in their brains. Thus, situations involving conflict have an impact on the brain, evoke biochemical reactions in the brain and physiological reactions in the entire organism, and result in a strong effect on human behavior way. Excitement, stress, and reactive or impulsive aggression (Dorfman et al. 2014) are connected with these reactions. They are shared by most primates (Barr \& Driscoll 2014). However, these biologically and environmentally boosted behaviors do not occur in a deterministic manner. People are overwhelmed by their aggressive reactions as long as their cognitive ability to navigate their action remains poorly developed. The human mind's developmental potential includes its ability to be modulated and set into trained cognitive self-control (before social control and sanctions enter), or at least a large part of them can be. Of course there are differences between children, young adults and adolescents (Buchmann et al. 2014) related to the developmental processes. The details are beyond the scope of this work, but we can refer to the developmental time window in which the prevention of aggressive behavior is still possible. Frans de Waal and other primatologists assume that, similarly to other primates, humans (including children) are provided with a "natural" ability to resolve conflicts. But humans often face non-natural conflicts and tensions produced by other humans. Those conflicts may weaken their evolutionary ability to resolve conflicts in a conciliatory way and "to interact subsequently in a friendly manner" (Cords \& Aureli 2000, 177), and even stimulate the development of aggression. Thus, one has to rethink the problem of aggression beyond natural history, within contemporary social realities, however, without reducing it to normative patterns, the post-conflict peacemaking tendency, or post-tantrum affiliation naturally increasing with age, as was observed in various cultures by Butovskaya et al. (2000). What is often described as "natural," most probably results from the socially stimulated growth, stagnation or regression (Lind $1985^{\mathrm{A}}$ ) of moral cognition. We call that cognition socio-moral competence and try to explain its central role in aggression control and prevention. It is quiet low in those who show far-right and ultraconservative convictions and, at the same time, more likely accept violence towards immigrants and refugees, as the recent Polish report of Centrum Badań nad Uprzedzeniami (CBU) (Bieńkowski \& Świderska 2017; see also Nowak \& Steć 2017) shows. 


\section{Reactive Aggression and Emotion vs. Proactive Aggression and Cognition}

Researchers have identified reactive aggression as the most common type of aggression in school-aged children; it is connected with such phenomena as hyperactivity, attention deficits, stimulation seeking, anxiety, impulsivity, and low school motivation. "Reactive aggression has been conceptualized as a fear-induced, irritable, and hostile affect-laden defensive response to provocation" (Raine et al 1998, 161; compare Dodge 1991 and Meloy 1988). Reactive aggression "involves a lack of inhibitory functions, reduced selfcontrol, and increased impulsivity" (Raine et al. 1998, 181). The opposite of proactive aggression, reactive aggression requires a high level of emotion and a low level of resistance to provocation and frustration. It is also characterized by feelings of guilt and outbursts of anger when the individual is confronted with an interpersonal conflict. All these characteristics indicate the low level of conscious emotions and cognitively governed affectivity. Strong and difficult emotions prevail, "drive" behavior immediately, and overwhelm cognitive processing in the face of a demanding decision context including controversy, cognitive and affective dissonance, time pressure, and other factors making decisions difficult for decision makers. This is one of the core reasons for strengthening moral cognition.

Dodge (1991) noted that "proactive aggression in the human and animal literature has been characterized as instrumental, organized, and 'coldblooded', with little evidence of autonomic arousal” (pp. 374-393). In proactive aggression, a low need for social contacts with peers and adults, a low affective level, and a low intrinsic motivation occur in combination. Proactive aggression is "characterized by (...) blunted affect and stimulation-seeking tendencies" (Dodge 1991, 374-393). Olweus (1994) stated that proactive aggression seems to be rooted in complex cognitive, conscious and even reflected processes, rather than in a spontaneous emotional reaction. It is too disconnected from empathy, "affective primacy" (Piaget 1981, 11-74; 1976, 8) and the "affective exchange" with others (Lind 1985b).

\section{Cognitive Empathy}

Does empathy provide humans with a restraint against the development of aggressive behavior? After two decades of empathy renaissance in evolutionary neuropsychology, recent research seems to be revising a longstanding consensus (see Knoch et al. 20064) about the role of empathy in moral

4 The research findings of Knoch et al. (2006) explored the psychopathological sources of low empathetic moral decision-making: "patients with right prefrontal lesions are characterized by the inability to behave in normatively appropriate ways despite the 
cognition, as well as about the definitions of both empathy and the sociopathic/psychopatic traits of human behavior. As Bloom's (2017) reports, fMRI experiments with football fans showed that watching a suffering fellow of the opposite fan club excited the brain areas responsible for pleasure in the participants of the experiment, while watching a suffering fellow of the same club was more likely to excite empathy for pain (Bloom 2017, 2016; Lamm \& Majdandžić 2015). Furthermore, as Avenanti et al. (2010) showed, compassion and empathy on a very basic interpersonal reaction level is diminished when people face fellow humans belonging to a racial/ethnic outgroup. The research findings reported above stress the fact that "antisocial behavior", which is "a particularly frequent problem during childhood and a predictor of later criminality" (Lösel \& Beelman 2007, 84-109), may be rooted in, and boosted by, numerous factors. Some of them lie beyond a person's selfconsciousness and self-control, but the self-control can be improved, trained and re-rained. Discovering that evolutionary, genetically, environmentally and physiologically supported empathy - and sympathy or compassion - might be more likely within same, homogeneous (ethnic, racial) tribe must be interpreted as a warning signal. That warning signal should encourage education, socialisation and resocialisation researchers to develop training for strengthening the cognitive kinds of empathy, disconnected from raw affection and spontaneous emotion. For Paul Bloom $(2013,2017)$ and Tania Singer, empathy means something very different, e.g., less physiological reactionrelated, less biased, but a more justice-oriented and prosocial attitude, i.e. notably cognitive in nature. It involves respect, open-mindedness, charity, solidarity, care and support.

Undoubtedly, low empathy (be it cognitive or emotional5) and aggression are not synonyms. It is rather that the growth of cognitive empathy and moral competence contributes to better self-control of aggression. A violence-free life context protects against the escalation of the aggressive tendency: "(...) exposure to violence may affect children's adaptation and functioning. This perspective emphasizes that a child's ultimate adaptation or

fact that they possess the judgmental abilities necessary for normative behavior, supporting the importance of right prefrontal areas for normatively appropriate behaviors. Thus, a dysfunction of the right DLPFC, or its specific connections, may underlay certain psychopathological disorders that are characterized by excessive selfish tendencies and a failure to obey basic social norms (...). Finally, the reported findings provide evidence for theoretical approaches to social cognition and decisionmaking that stress the fundamental role of DLPFC in neural networks that support deliberative processes in human decision-making" (Knoch et al. 2006).

${ }^{5}$ Bloom (2016) shows that persons open for high excitement and affection more often tend to violent behavior, for ex. they require stronger revenge and punishments for offenders, allow militant sanctions and physical violence as political power means, and they allow tortures in interrogation. A strong emotional identification with particular persons leads to discrimination against others and to the omission of the entire group, society, humanity, common goods, interests, and holistic justice. 
maladaptation occurs as a result of the interplay between the evolving individual and changing contextual factors (e.g., the family environment), underlining the importance of mediating variables that may contribute to outcomes" (Yoon 2015, 106). In the last decade, European societies have experienced an increase in social aggression as a result of people's low sociomoral competence, which has been challenged by new intercultural and multiethnic experiences, dilemmas and conflicts. We decided to revisit and revise our research findings gathered during a program offered to young offenders and the aggressive children of immigrants we trained in 2009-2010 in Poland and Switzerland. We did this because these research findings show that using an appropriate training program can promote both moral competence and cognitive empathy in juveniles to protect them against the growth of aggression, harassment, discrimination etc. During years that passed between our pilot study and today we have observed how the tendency of aggressive behavior has been increasing, along with social tolerance of violence, in particular in the Middle-European, still mono-ethnic subcultures and far-right groups. We are far from saying that any particular ethnic, cultural or religious group is more susceptible to, or tolerant of violence than other groups. Aggression which manifests itself in various observable forms of behavior is always interrelated with the environment in both the biological and social context. Biological reactions, instincts and intuitions are not enough to handle social contexts which work in a different way than those in an animal herd, or archaic tribe. The extremist groups (Lind 1998) seem to follow tribal behavioral patterns including lynching, vendetta (Nowak 2015), and terror.

We agree with scholars who strongly advocate social-cognitive development (called reason in rationalist philosophy) and the use of cognitive skills in modern social contexts. Living as a Socius requires cognitive strength, which needs to be trained and retrained to better face the new opportunities and challenges created by social and technological progress. Humans create and manage their complex habitat by means of their cognitive skills so they gradually stop following their animal instinctive compass (Gehlen 1986). Cognition should replace that compass. In the other case, humans are doomed to helplessness, or developing risky and violent behaviors. Negotiating social conflicts' solutions by brutal means is one of them. In this paper, we are not interested in how can societies protect themselves against aggressors; we rather ask, how to protect an average individual against becoming aggressor.

Fortunately, the development in education provides teachers of all levels with useful methods for promoting moral cognition, moral competence and cognitive empathy, as well as with measuring instruments to assess the efficiency of these methods. KMDD is undoubtedly a leading one (Lind 2016; Nowak 2013; Lind \& Nowak 2015; Lind \& Nowak 2009). We applied it in 2010 in our pilot study as a tool for the prevention of aggression and cognitive development. Next studies followed (Nowak 2013; Nowak \& Steć 2017). 


\section{Two KMDD and MCT Based Pilot Studies on Aggression Prevention with Juveniles in Poland and Switzerland}

We offered dilemma-discussion training in two educational institutions: 1) a reform institution for juvenile female offenders integrated with high school (Wielkopolska voivodeship), and 2) a Swiss primary school (Kanton Thurgau), we initiated the project "Aggression Prevention with KMDD" (Schillinger, Nowak, \& Urbańska 2009). Group 1 included female offenders aged 13-21 $(\mathrm{N}=14)$ from Poland. Group 2 included multicultural juveniles $(\mathrm{N}=13$, gender characteristics: 6 males, 7 females) with hyperactivity and an observable aggressive tendency in male immigrants.

The training composed of 5 to 10 KMDD sessions 90 minutes each and was thought of as an experimental program of aggression prevention (proactive aggression). The core measurement instrument was the Moral Competence Test (Lind 1984, 1986, 2002, 2010, 2016; Bargel et al 1982). Data on aggressive behavior tendencies (in particular anger and anxiety) and violent behavior were self-reported and collected with the help of the ReactiveProactive Aggression Questionnaire (Raine \& Dodge 2006). Observations of violent behavior were reported by class teachers who used the Gasteiger Form.

Georg Lind created a precise experimental instrument (MCT) to measure the growth of moral competence as a result of moral competence training. The MCT is based on two dilemmas (i.e., moral tasks to be resolved by participants) provided with 12 arguments each (6 in favor and 6 against the solution of the dilemma, 24 arguments all together). It assesses the manifest judgment behavior of participants who evaluate solutions to dilemmas, as well as arguments designed according to the six different types of moral orientation (Lind 2016, 67).

"The MCT produces what is called a 'C-score', the ' $\mathrm{C}$ ' standing for competence. The $\mathrm{C}$-score indicates to which degree a participant rates the argument of the best by their moral quality, rather than by other factors like their opinion agreement. In other words, the C-score is designed to show how able people are to engage in a moral discussion with a difficult issue rather than obstruct it by insisting on their opinion regardless of what speaks in its favor or against it. (...) The $\mathrm{C}$-score has been constructed so that it ranges from 0 to 100. A C-score of zero means that the individual's pattern of responses to the MCT does not manifest any moral competence. A C-score of one hundred [C-points] means that the individual's response pattern perfectly meets the criterion of moral competence" (Lind 2016, 69).

In the group of Polish female juveniles, a moral competence growth of $10 \mathrm{C}$ pointswas achieved after 8 KMDD sessions conducted over several months.

This pilot study found that young delinquent females with lower levels of physical violence (blue-marked graph) achieved much better results from the dilemma discussion trainings than females with higher levels (red-marked 
graph). However, both groups reported strong anxiety. All the participants were observed by teachers for a period of eight months. The teachers observed that the "blue" group members participated more actively in all the phases of the dilemma discussions, and they showed increasing emotional self-control, even when confronted with controversies and opposing views in the group discussions during the KMDD sessions. In contrast, the "red" group members often showed anxiety and uncontrolled emotions. The "red" group had more difficulty with translating affects to verbal expressions, arguments and counterarguments. All the participants were engaged in the KMDD sessions throughout the dilemma presentations and for a few minutes afterwards. They later asked for more dilemma-stories just "to listen" and to experience their dramatic impact. Understanding and expressing their own conflicting feelings and intuitive judgments seemed to overwhelm them. As KMDD instructors, we observed signs of interpersonal hostility and anxiety, in particular during the voting phase of the dilemma discussions. Black blindfolds were used to avoid quarrels about voting in favor/against the decision made by the protagonists of the dilemmas.

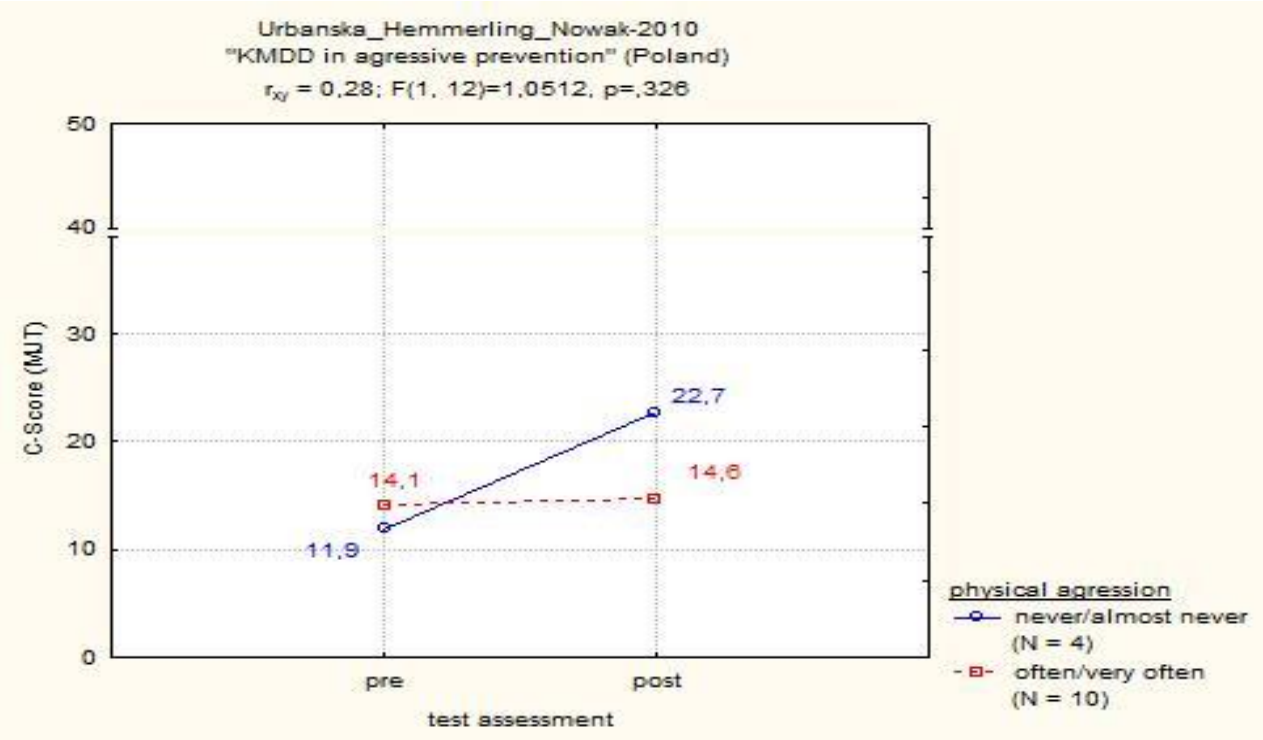

Figure 1. Konstanz Method of Dilemma-Discussion in a reform institution for female juvenile offenders (Urbańska, Schillinger, Hemmerling, \& Nowak, Poland 2010).

One more issue could be discussed in the context of gender (Friedman 1985). During the KMDD sessions with Swiss pupils and young Polish delinquent females, no moral deficiency of females in comparison to males was observed. We avoided selecting gender-related dilemma stories and offered stories with gender-balanced contents, covering the topics of care, justice, responsibility, 
and common social norms. No gender gap in the moral orientations expressed in the participants' speeches was observable; only some particular differences ${ }^{6}$.

It was very different in the Swiss primary school children's training.

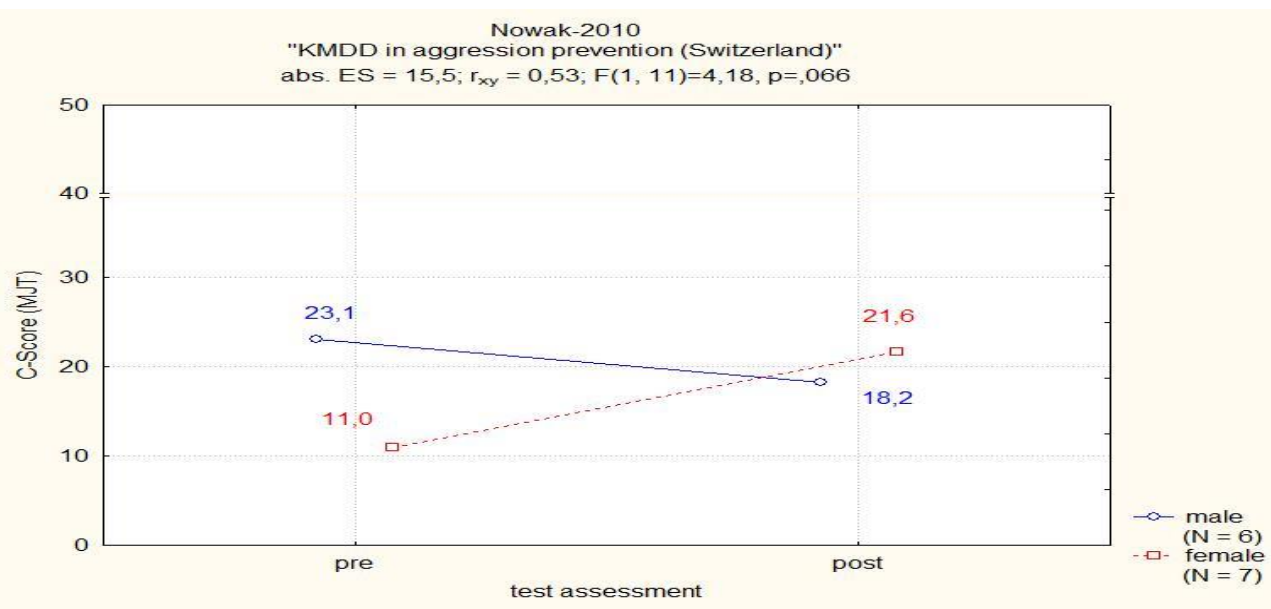

Figure 2. Swiss primary school pupils (70\% of immigrant descents) MCT study.

We observed two different phenomena in a Swiss group of 11-year-old male and female pupils in a multiethnic class with learning problems, low Germanlanguage competency, hyperactivity, emotional aggression and anxiety, harassment, hate speech and fights, which were reported by the class teachers. After two dilemma discussions, the boys already started controlling their overexcitement and showiness, and behaved much better than they did at the beginning of our intervention. In addition, the girls became less fearful and increasingly talkative. They engaged in the discussions, and their speeches and arguments became noticeably longer and better ordered over time. The girls learned to speak, and the boys learned to listen. We did not observe anxious behavior in the classroom. At the end of the KMDD-intervention, both the girls and boys stated that they appreciated "the different viewpoints because it is really interesting to know how people think." Even very shy children and children sitting at corner tables started cooperating with others (in contrast to the strong exclusion that we observed earlier). Using the same measuring instruments (MCT, Dodge Scale and Gasteiger Questionnaire) the findings showed increased competence in moral judgment; however, this was mainly among girls (over $10 \mathrm{C}$-points). During the post-MCT conducted in the group, all the male students were extremely excited by the football match that followed

\footnotetext{
${ }^{6}$ Just to recall: "In Moral Stages, Kohlberg has argued that justice and caring are not 'two different tracks of moral development which are either independent or in polar opposition to one another,' that 'many moral situations or dilemmas do not pose a choice between one or the other orientation, but rather call out a response which integrates both orientations,' and that considerations of caring need not conflict with those of justice 'but may be integrated into a response consistent with justice, especially at the postconventional level'" (Friedman 1985, 28).
} 
after our meeting in the classroom. Their hearts all belonged to the Football World Cup finale 2010.

Based on these findings, we suggest that dilemma discussion training at an early school age could help children to understand and verbally and rationally "construct" (Lind 2010) their affects at a conscious level and, finally, to train their moral competence. Furthermore, a moral and democratic education would facilitate the achievement of these goals if teachers were encouraged to apply the highly efficient didactic principles of the Konstanz Method of Dilemma Discussion in other school subjects. Guided dilemmatic reflection, cooperative reasoning with peers personifying very different views, dealing with opposite views in peaceful, verbal and non-verbal communication, and experiencing how conflicts can be resolved by a rational and dialogical inquiry instead of physical violence, insult, bullying, discrimination, etc. could serve to strengthen all kinds of socio-moral competences and to minimize the risk of aggression in societies (Holditch-Niolon et al. 2015). In the Swiss group, we observed an evolving dialogical readiness and reciprocal inclusion across four different nationalities. The participants were engaged in deliberating on the dilemmas and conflicts typical for everyday life, despite cultural differences. Similarly, increasing reciprocal attentiveness and recognition were observed during our KMDD trainings in other Polish groups in which estrangement and tensions were resolved and mutual respect increased. To conclude in Habermas' terms, personal behavior and interpersonal relations in which personal moral and discourse competencies manifest themselves is a precondition for the rationalisation of society. Rationalisation does not begin purely from abstract principles and procedures; the same goes for democracy, which does not begin only with constitutions and philosophical treatises, but also in human minds and interhuman relationships (Nowak 2013). Experiences reported in this paper might be supportive for teachers, professionals and lay persons faced with everyday forms of aggressive behavior, in particular in multiethnic and multicultural school contexts. Those teachers can involve the KMDD, or its elements, in their regular classes in order to foster moral competence in pupils. At the same time, more specific and advanced forms of aggression, harassment, bullying etc. require special therapeutic programs (see Schanzenbächer 2003, Weidner 2001) to which a dilemma discussion may too contribute as a powerful facilitator of moral-cognitive development.

\section{References}

Apel, K.-A. 1990. Diskurs und Verantwortung. Frankfurt/M.: Suhrkamp.

Avenanti, A., Sirigu, A., \& Agliotii, S. M. 2010. Racial Bias Reduces Empathic Sensorimotor Resonance With Other-Race Pain. Current Biology, 20, 1018-22. 
Bartels, D. 2008. Principled Moral Sentiment and the Flexibility of Moral Judgment And Decision Making. Cognition, 108, 381-417.

Bieńkowski, M. \& Świderska, A. 2017. Postawy wobec imigrantów i uchodźców. Panel Badań Społecznych CBU. Retrieved from cbu.psychologia.pl on August 7, 2017.

Bloom, P. 2017. Mściciel z empatią, interview with Paul Bloom. Ed. by $\quad$ M. Rotkiewicz. Polityka, 27(3117), 5.07.2017: 56-58.

Bloom, P. 2016. Against Empathy: The Case for Rational Compassion. New York: The Ecco Press - Harper Collins Publishers.

Brehm, J. W. \& Cohen, A. R. 1962. Exploration in Cognitive Dissonance. New York: Wiley.

Butler, J. 2004. Precarious Life. The Powers of Mourning and Violence. New York: Verso.

Butovskaya, M., Verbeek, P., Ljungberg, T., \& Lunardini, A. 2000. A Multicultural View of Peacemaking Among Young Children. In F. Aureli \& F. De Waal, Natural Conflict Resolution. Berkeley - Los Angeles - London: University of California Press, pp. 243-252).

Cavelzani, A. \& Esposito, M. 2010. Emotional Intelligence \& Hospitality. Tate Publishing (e-Book).

DiDenti Christiansen, E. 2010. Adolescent Cape Verdean Girls' Experiences of Violence, Incarceration, and Deportation: Developing Resources Through Participatory Community-Based Groups. International Journal of Intercultural Relations, 34, 127-140.

Dodge, K. A. et al. 2003. Peer Rejection and Social Information-Processing Factors in the Development of Aggressive Behavior Problems in Children. Child Development, 74 (2), 374-393.

Freire, P. 2005. Pedagogy of the Opressed. New York - London: Continuum.

Friedman, M. 1985. Abraham, Socrates, and Heinz: Where Are the Women? (Care and Context in Moral Reasoning). In C. Gibb Harding (ed.) Moral Dilemmas. Philosophical and Psychological Issues in the Development of Moral Resoning. Chicago: Precedent Publishing, Inc., pp. 25-42.

Gehlen, A. 1986. Der Mensch. Seine Natur und seine Stellung in der Welt. Wiesbaden: Aula Verlag.

Gower A. L., Shlafer R. et al. 2014. Brief Report: Associations Between Adolescent Girls' Social-Emotional Intelligence and Violence Perpetration. Journal of Adolescence, 37, 67-71.

Greene, J. D., Sommerville, R. B., Nystrom, L. E., Darley, J. M., \& Cohen, J. D. 2001. An fMRI Investigation of Emotional Engagement in Moral Judgment. Science, 293(5537), 2105-2108.

Greene, J. D. 2009. Dual-Process Morality And the Personal/Impersonal Distinction: A Reply to McGuire, Langdon, Coltheart, and Mackenzie. Journal of Experimental Social Psychology, 45, 581-584.

Greene, J. D. 2015. The Rise of Moral Cognition. Cognition, 135, 39-42. 
Habermas, J. 1985. Autonomy and Solidarity. Interviews with Jürgen Habermas. London - New York: Verso.

Habermas, J. 1984. The Theory of Communicative Action. Vol. 1, Reason and the Rationalisation of Society. Boston: Beacon Press.

Haidt, J. 2001. The Emotional Dog and Its Rational Tail: A Social Intuitionist Approach To Moral Judgment. Psychological Review, 108, 814-834.

Hamlin, J. K. et al. 2007. Social Evaluation By Preverbal Infants. Nature, 450 (7169), 557-559.

Hemmerling, K. 2014. Morality Behind Bars: An Intervention Study on Fostering Moral Competence of Prisoners As a New Approach To Social Rehabilitation. Frankfurt/M.: Peter Lang Edition.

Hemmerling, K., Scharlipp, M., \& Lind, G. 2009. Die Konstanzer Methode der Dilemma Diskussion für die Bildungsarbeit mit Risikogruppen, in K. Mayer \& H. Schildknecht (eds) Handbuch Dissozialität, Delinquenz und Kriminalität-Grundlagen und Methoden der professionellen Arbeit mit Menschen mit abweichendem Verhalten. Zürich: Schulthess.

Holditch Niolon, Ph. et al. 2015. Prevalence of Teen Dating Violence and Cooccurring Risk Factors Among Middle School Youth in High-Risk Urban Communities. Journal of Adolescent Health, 56, S5-S13.

Koch, D. et al. 2006. Diminishing Reciprocal Fairness By Disrupting the Right Prefrontal Cortex. Science Express, http://science.sciencemag.org/content/sci/early/2006/10/05/scienc e.1129156.full.pdf (retrieved on February 15, 2017).

Koyama, H. 2012. Freedom and Power in the Thought of Hannah Arendt: Civil Disobedience and the Politics of Theatre. Theoria. A Journal of Social and Political Theory, 59(133), 70-80.

Lamm, C. \& Majdandžić, J. 2015. The Role of Shared Neural Activations, Mirror Neurons, and Morality in Empathy - A Critical Comment. Neuroscience Research, 90, 15-24.

Lind, G. 1997. Gewalt als die niedrigste Ebene der Konfliktlösung. Ethics in Progress Quarterly, 1 (2010). Paper presented at the $10^{\text {th }}$ Conference of Peace Psychology, University of Konstanz, 13.-15.06.1997.

Lind, G. 1998. Gewalt und Krieg als die niedrigste Stufe der Konfliktbewältigung, in W. Kempf \& I. Schmidt-Regener (eds) Krieg. Nationalismus, Rassismus und die Medien. Münster: LIT Verlag, pp. 271-282.

Lind, G. 1985a. Growth and Regression on Cognitive-Moral Development, in C. Gibb Harding (ed.) Moral Dilemmas. Chicago: Precedent Publishing, pp. 99-114.

Lind, G. 1982. Integrating Affect And Cognition: The Concept of 'Experimental Questionnaires' For Evaluating Educational Programs. Paper presented at the International Symposium on Moral Education, Fribourg (Switzerland).

Lind, G. 2002. Ist Moral lehrbar? München: Logos. 
Lind, G. 2010. Moral Education. A Dual-Aspect Theory. In E. Kiel \& K. Zierer (eds) Gestaltung Basisunterricht (in German). English hand-out.

Lind, G. 1993. Zur Psychologie gewalttätigen Verhaltens und seiner Prävention. Psychology of Morality \& Democracy and Education. Retrieved from: http://www.uni-konstanz.de/ag-moral/pdf/Lind-1993_GewaltTheorien.pdf.

Lind, G. 1985b. Parallelität von Affekt und Kognition in der moralischen Entwicklung, in F. Oser, W. Althoff, \& D. Garz (eds) Entstehung moralischer Identität, Soziogenese, moralisches Handeln und Schuld. München: Peter Kindt.

Lind, G. \& Nowak, E. 2015. Kohlberg's Unnoticed Dilemma - The External Assessment of Internal Moral Competence?, in B. Zizek, D. Garz, \& E. Nowak (eds) Kohlberg Revisited. Rotterdam: Sense Publishers, pp. 139154.

Lind, G. \& Nowak, E. 2009. Mis-Educative Martial Law: The Fate of Free Discourse and the Moral Judgment Competence of Polish University Students From 1977 To 1983. In B. Wojciechowski \& M. Zirk-Sadowski (eds) Between Complexity of Law and Lack of Order, Torun - Bejing. Adam Marszałek Publishing, pp. 145-165. Paper presented at the AME Congress in New York, New York University 2007.

Lipsey, M. W. et al. 2001. Cognitive-Behavioral Programs for Offenders. The Annals of the American Academy of Political and Social Science, 578, 144-157.

Lösel, F. \& Beelmann, A. 2003. Effects of Child Skills Training in Preventing Antisocial Behavior: A Systematic Review of Randomized Evaluations. The Annals of the American Academy of Political and Social Science, 587(1), 84-109.

Lösel, F. 2008. Präventionseffekte sozialer Kompetenztraining für Kinder. Erlangen: Stiftung Deutsches Forum für Kriminalprävention (PDFdocument).

Olweus, D. 1994. Bullying at School: Long-Term Outcomes for the Victims and an Effective School-Based Intervention Program. Aggressive Behavior: Current Perspectives. New York: Plenum, pp. 97-130.

Oswald, P. A. 1996. The Effects of Cognitive and Affective Perspective-Taking on Empathic Concern and Altruistic Helping. Journal of Social Psychology, (136), 613-623.

Nowak, E. 2013. Democracy Begins in the Mind Developing Democratic Personality, in E. Nowak, B. Zizek \& D. E. Schrader (eds) Educating Competencies for Democracy. Frankfurt am Main - Berlin - Bruxelles New York - Oxford - Warszawa - Wien: Peter Lang Publishing, pp. 399-416.

Nowak, E. 2015. Mediterranean Drama: Pragmatic, Legal and Moral Aspects of Hospitality. Public Philosophy and Democratic Education, 4(2), 144-162. 
Nowak, E. \& Steć, M. 2017. Linking Moral Competence, Hospitality and Education. An MCT based Pilot Survey, in R. Franzini Tibaldeo \& G. Lingua (eds) Philosophy \& Community Practices. Bern - Bruxelles - New York - Warsaw - Frankfurt/M.: Peter Lang Publishing.

Pearson, J. (ed.). 2001. Michel Foucault. Fearless Speech. Los Angeles: Semiotext(e).

Piaget, J. 1981. Intelligence and Affectivity. Palo Alto: Annual Reviews Monograph.

Piaget, J. 1965. The Moral Judgment of the Child. New York: The Free Press.

Radbruch, G. 1993. Politische Schriften aus der Weimarer Zeit. Bildungs- und Religionspolitik, vol. 2. Heidelberg: C. F. Müller Verlag.

Radbruch, G. 2003. Rechtsphilosophie. Studienausgabe, 2. Aufl. Hg. v. R. Dreier \& S. L. Paulson. Heidelberg: C.F. Müller Verlag.

Rawls, J. 1999. The Theory of Justice. Harvard University Press.

Raine, A. \& Dodge, K. A. 2006. The Reactive-Proactive Aggression Questionnaire: Differential Correlates of Reactive and Proactive Aggression in Adolescent Boys. Aggressive Behavior, 32, 159-171.

Richardson, D. R. et al. 1988. Relationship Between Perspective-Taking and Non-Aggressive Responding in the Face of An Attack. Journal of Personality, 66(2), 235-256.

Roberts, W. \& Strayer, J. 1996. Empathy, Emotional Expressiveness, and Prosocial Behaviour. Child Development, 67(2), 449-470.

Schanzenbächer, S. 2003. Anti-Aggressivitäts-Training auf dem Prüfstand. Behandlung der Gewalttäter lohnt sich. Freiburg: Centaurus Verlag \& Media.

Schillinger, M. 2006. Learning Environment and Moral Development. Aachen: Shaker.

Shlafer, R. J., McMorris, B. J. et al. 2013. The Impact of Family and Peer Protective Factors on Girls' Violence Perpetration and Victimization. Journal of Adolescent Health, 52, 365-371.

Sloterdijk, P. 2010. Rage and Time - A Psychopolitical Investigation. Tr. M. Wenning. New York: Columbia Univ. Press.

Thoreau, H. D. 1849. On the Duty of Civil Disobedience. Project Gutenberg, retrieved from http://www.gutenberg.org/files/71/71-h/71-h.htm (on May 20, 2016).

Weidner, J. 2001. Anti-Aggressivitäts-Training für Gewalttäter. Mönchengladbach: Forum Verlag Godesberg.

Zimbardo, Ph. 2007. The Lucifer Effect. Understanding Howe Good People Turn Evil. New York: Random House.

Yoon, S., Kobulsky, J. M. et al. 2015. Gender Differences in Caregiver-Child Relationship Mediation of the Association Between Violence Exposure Severity and Adolescent Behavior Problems. Child Abuse \& Neglect, 50, 104-115. 
Ewa Nowak \& Adrianna Urbsḱa

(Adam Mickiewicz University of Poznań, ewanowak@bluewin.ch, urbanska@gmail.com)

Moral Competence and Aggression Prevention. Updating MCT Pilot Studies Inspired By Georg Lind's Book "How to Teach Morality. Promoting Deliberation and Discussion, Reducing Violence and Deceit" (2016)

\begin{abstract}
Aggression in juveniles may increase even in modern societies and manifest itself in countless forms of violence, including harming, persecution, abuse, pressure, hostility, etc. A large number of studies on the evolutionary, psychological and sociological origins of aggression are available. However, we lack cognitive remedies to counter developing tendencies towards aggressive behavior. Georg Lind's book How to teach morality. Promoting deliberation and discussion, reducing violence and deceit (2016) offers such a remedy based on his long-term (1976-2017) experiences with dilemma discussion training. This paper draws on Lind's conception of strengthening socio-moral competence as the most efficient remedy against aggression. It also revisits the ongoing theories of empathy. Finally, it revises the pilot research study that we conducted 2010 among Polish and Swiss juveniles7. That study focused on the following hypotheses: Lind's method of dilemma discussion (KMDD) can train and retrain moral competence in juveniles that show a slight inclination towards aggressive behavior. Strong moral competence may prevent further maldevelopment, in particular interpersonal and collective violence.
\end{abstract}

Keywords: aggression prevention, KMDD, MCT, dilemma discussion, moral-cognitive development, Polish-Swiss pilot study, Georg Lind, Paul Bloom.

Ethics in Progress (ISSN 2084-9257). Vol. 8 (2017). No. 1, Art. \#13, pp. 207-224.

Creative Commons BY-SA 3.0

Doi: 10.14746/eip.2017.1.13

7 The first draft of this paper appeared in 2011 in Journal of Strategy and Decision Making, Fall October, pp. 77-85. A considerably updated version is presented here. 